\title{
saki
}

\section{FAKTOR PENGARUH PERTUMBUHAN KREDIT PERBANKAN DI INDONESIA}

\author{
Ganis Samodro Priyaninggar \\ Sekolah Bisnis dan Ekonomi, Universitas Prasetiya Mulya \\ Edu Town Kavling Edu I No. 1, Serpong, Jl. BSD Raya Utama, \\ Pagedangan, Tangerang, Banten 15339
}

\begin{abstract}
The aim of the research is analyzing main significant factors that influence bank's credit growth of BUKU 4 in Indonesia. Researchers obtained the data from bank's financial reports from quarter 2 in 2005 until quarter 2 in 2015. This research gives contribution to Indonesian banks in forecasting the upcoming credit growth. The results show that third party fund, Capital Adequacy Ratio (CAR), Non Performing Loan (NPL), BI Rate, Gross Domestic Product (PDB) significantly affect the bank's credit growth. While, inflation, Net Interest Margin (NIM), and exchange rates do not affect significantly. These results support the previous research done by Oktaviani and Pangestuti (2012) for third party fund and Capital Adequacy Ratio (CAR), Ivanovic (2015) for Non Performing Loan (NPL) and Rahayu (2013) for BI rates.
\end{abstract}

Key words: third party fund (DPK), Non Performing Loan (NPL), bank's credit growth, Gross Domestic Product (PDB), Capital Adequacy Ratio (CAR), BI Rate.

\section{SARI PATI}

Tujuan penilitian ini adalah menganalisa faktor signikan pertumbuhan kredit perbankan pada BUKU 4 di Indonesia. Data diperoleh dari laporan keuangan bank dari kuartal 2 tahun 2005 hingga kuartal 2 tahun 2015. Penelitian ini berkontribusi meramalkan pertumbuhan kredit perbankan Indonesia pada periode mendatang. Hal ini menunjukan bahwa Dana Pihak Ketiga (DPK), rasio kecukupan modal, kredit bermasalah, Suku Bunga Bank Indonesia (SBBI), dan Produk Domestik Bruto (PDB) berpengaruh signifikan bagi pertumbuhan kredit perbankan di Indonesia, sementara inflasi, penghasilan bunga bersih, dan nilai tukar Rupiah tidak berpengaruh signifikan. Hasil ini mendukung penelitian Oktaviani dan Pangestuti (2012 untuk faktor Dana Pihak Ketiga (DPK) dan rasio kecukupan modal, Ivanovic (2015) untuk kredit bermasalah dan Rahayu (2013) untuk Suku Bunga Bank Indonesia (SBBI).

\section{Kata Kunci:}

Dana Pihak Ketiga (DPK), Kredit bermasalah, Pertumbuhan kredit perbankan, Produk Domestik Bruto (PDB), Rasio kecukupan modal, Suku Bunga Bank Indonesia (SBBI).

\section{PENDAHULUAN}

Faktor penting pencapaian target pertumbuhan ekonomi adalah pendanaan dari pinjaman bank dan pasar modal. Sebagian besar perusahaan di Indonesia masih mengandalkan kredit perbankan sebagai sumber pendanaan. Karena itu sangat penting melakukan analisis pertumbuhan kredit perbankan. Tiga pihak yang perlu melakukan analisis pertumbuhan kredit ialah pemerintah, Bank Indonesia (BI), dan perusahaan. 


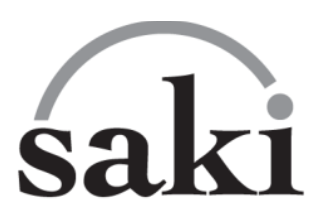

Studi Akuntansi \& Keuangan Indonesia

Dua indikator simultan untuk menganalisis pertumbuhan kredit yaitu faktor internal dan eksternal. Faktor-faktor internal diantaranya ialah rasio kecukupan modal, kredit bermasalah, penghasilan bunga bersih, dan Dana Pihak Ketiga (DPK). Sementara faktor-faktor eksternal adalah Produk Domestik Bruto (PDB), tingkat Suku Bunga Bank Indonesia (SBBI), laju inflasi dan nilai tukarRupiah. Karena itu penulis menganalisa kedua faktor tersebut terhadap pertumbuhan kredit perbankan pada Bank Umum Kelompok Usaha (BUKU)4.

Manfaat penelitian ini ialah bank berfokus pada variabel yang signifikan apabila ingin meningkatkan pertumbuhan kredit pada periode mendatang. Di saat yang bersamaan bank dapat melihat kinerja internalnya sehingga lebih termotivasi untuk bersaing dengan bank lain serta memprediksi kinerja pesaingnya. Batasan penelitan ini adalah bank-bank yang termasuk kategori BUKU 4 di Indonesia dan data historis yang diambil dalam jangka waktu kuartal 2 tahun 2005 hingga kuartal 2 tahun 2015.

\section{LANDASAN TEORI \& PENGEMBANGAN HIPOTESIS}

Perbankan Indonesia berfungsi sebagai lembaga intermediasi yang menghimpun dan menyalurkan kembali dana kepada masyarakat dalam bentuk kredit.. Dana tersebut terbagi dalam bentuk tabungan, giro, ataupun deposito berjangka atau disebut juga Dana Pihak Ketiga (DPK).

Untuk memahami kondisi keuangan perbankan diperlukan analisis terhadap laporan keuangannya. Laporan keuangan bank menurut jenisnya terdiri atas neraca bank, perhitungan laba rugi, dan laporan komitmen dan kontijensi (Veithzal et al., 2007).Neraca bank adalah suatu laporan keuangan yang diterbitkan setiap hari kerja oleh satuan kerja akunting. Laporan perhitungan laba rugi dari suatu bank umum adalah suatu laporan keuangan bank yang menggambarkan pendapatan dan biaya operasional dan nonoperasional bank serta keuntungan bersih bank untuk suatu periode tertentu. Sementara itu, laporan komitmen dan kontijensi adalah laporan yang mencatatkan transaksi-transaksi yang belum secara efektif mengakibatkan perubahan terhadap aktiva maupun kewajiban bank.

Neraca Bank terdiri dari; Batas Maksimum Pemberian Kredit (BMPK), Rasio Kecukupan Modal, Rasio Kredit Bermasalah, dan Dana Pihak Ketiga. BMPK adalah persentase perbandingan batas maksimum penyediaan dana yang diperkenankan terhadap modal bank. Hal ini telah diatur dalam Undang-undang Nomor 10 Tahun 1998 tentang perbankan dimana. Semantara itu dalam Peraturan Bank Indonesia (PBI) tertuang dalam No. 7/3/PBI/2005 pasal 4 dan pasal 11. Rasio kecukupan modal atau dikenal dengan istilah Capital Adequacy Ratio (CAR) adalah rasio perbandingan seluruh aset yang menjadi hak milik bank dan juga modal bersih yang dimiliki. Menurut PBI Nomor 14/18/PBI/2012 minimum rasio kecukupan modal adalah sebesar $8 \%$ dari Aset Tertimbang Menurut Risiko (ATMR) dengan catatan penilaian Bank. Aturan PBI tersebut merupakan bentu penerapan dari Basel Committee on Banking Supervision (BCBS) yang dibentuk pada tahun 1974 oleh para Gubernur Bank Sentral di negara-negara maju yang tergabung dalam Group of Ten (G $10)$.

Aturan BCBS telah diperbaharui hingga tiga kali. BaselIdifokuskan pada anitipasi atas risiko kredit dari kegagalan bisnis yang dilakukan oleh bank. Basel II bertujuan agar bank menjadi lebih sensitif terhadap risiko dengan memuat penyempurnaan perhitungan risiko kredit dan perhitungan risiko operasional. Basel III menyajikan reformasi yang dilakukan oleh BCBS untuk memperkuat permodalan dan standar likuiditas dengan tujuan untuk meningkatkan ketahanan sektor perbankan terhadap krisis. Pada Basel III juga diperkenalkan standar likuiditas jangka pendek/Liquidity Coverage Ratio (LCR) dan untuk jangka 
panjang/Net Stable Funding Ratio (NSFR). Bank Indonesia mengimplementasi Basel III dengan terus melakukan kajian sesuai dengan kondisi perbankan Indonesia. Rasio kecukupan modal dirumuskan sebagai berikut (Veithzal et al.,2007):
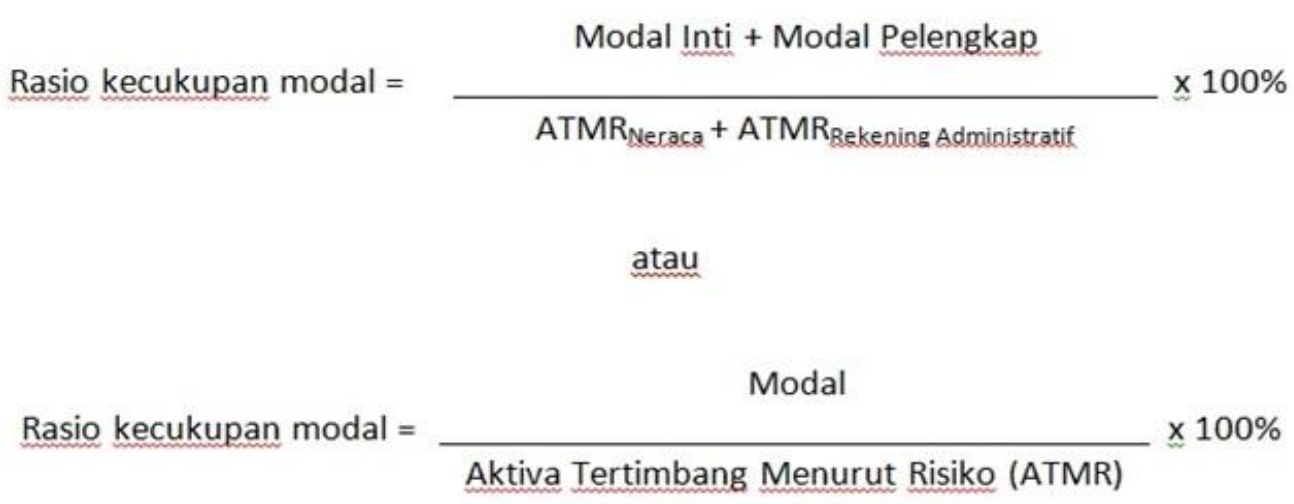

Analisa kredit bermasalah bertujuan mengidentifikasi adanya masalah dalam perbankan. Bank Indonesia menentukan 5\% sebagai batas rasio total kredit bermasalah. Perhitungan kredit bermasalah adalah sebagai berikut (Peraturan Bank Indonesia):

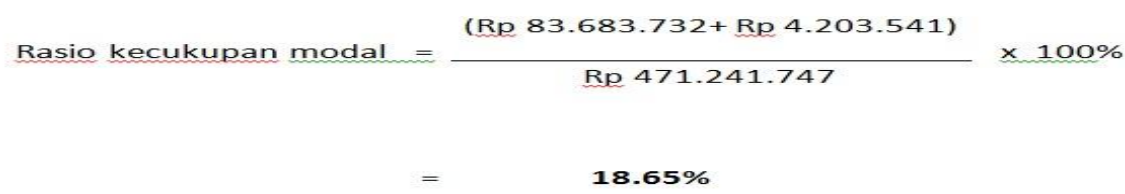

Dana Pihak Ketiga (DPK) /dana masyarakat adalah simpanan yang dihimpun oleh lembaga keuangan yang berasal dari masyarakat, baik individu maupun badan usaha dalam bentuk rupiah maupun valuta asing. Menurut Undang-undang No. 10 Tahun 1998 DPK bisa berupa giro, deposito, sertifikat deposito, tabungan dan atau bentuk lainnya yang dipersamakan dengan itu.

Contoh perhitungan Dana Pihak Ketiga(DPK):

Bank BCA memiliki giro sebesar Rp 115.680.814, tabungan Rp 244.608.317, dan simpanan berjangka sebesar Rp 113.409.347. Maka jumlah DPK Bank BCA adalah: Rp 115.689.814 + Rp 244.608.317 + Rp 113.409.347 = Rp 473.707.478

Penghasilan bunga bersih merupakan salah satu rasio yang dijadikan patokan oleh bank untuk mengetahui seberapa besar kemampuannya mengelola seluruh aktiva produktif agar dapat mengasilkan laba bersih yang lebih tinggi. Perhitungan rasio penghasilan bunga bersih dirumuskan sebagai berikut (Veithzal et al., 2007): 


\section{saki}

Studi Akuntansi \& Keuangan Indonesia

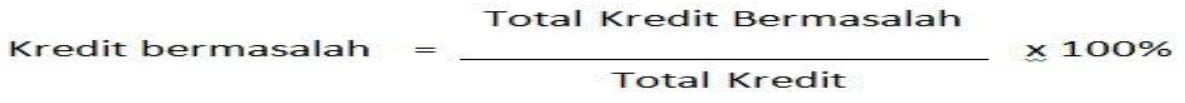

Pendapatan non-bunga (fee-based income) adalah pendapatan provisi dan komisi yang diterima bank dari fasilitas maupun transaksi jasa perbankan yang dibebankan kepada nasabah atas produk dan jasa yang dinikmatinya. Beberapa jasa perbankan yang menghasilkan pendapatan non bunga ialah transfer, inkaso, letter of credit, safe deposit box, dana pembayaran rekening titipan (payment point), bank garansi, jual beli atau perdagagan valuta asing, commercial paper dan traveller'scheck. Perhitungan rasio pendapatan non-bunga dirumuskan sebagai berikut (Veithzal et al., 2007):

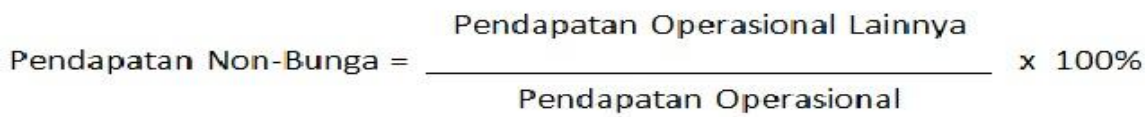

Laporan komitmen adalah suatu perikatan atau kontrak berupa janji yang tidak dapat dibatalkan secara sepihak. Lebih jelasnya dalam Pernyataan Standar Akuntansi Keuangan (PSAK) No. 31 Akuntansi Perbankan Bab 2 D dijelaskan bahwa komitmen adalah suatu ikatan atau kontrak berupa janji yang tidak dapat dibatalkan (irrevocable) secara sepihak, dan harus dilaksanakan apabila persyaratan yang disepakati bersama dipenuhi, seperti komitmen kredit, komitmen penjualan atau pembelian aktiva bank dengan syarat Repurchase Aggrement (REPO), serta komitmen penyediaan fasilitas perbankan lainnya. kontijensi adalah tagihan atau kewajiban bank yang kemungkinan timbulnya tergantung pada terjadi atau tidak terjadinya satu atau lebih peristiwa dimasa yang akan datang (Standar Akuntansi Keuangan (PSAK) No. 31 Akuntansi Perbankan Bab 2 D).

Produk Domestik Bruto (PDB) atau Gross Domestic Product (GDP) merupakan nilai akhir dari barang dan jasa yang diproduksi suatu negara sebagai suatu bentuk kegiatan ekonomi dalam kurun waktu tertentu.

Perhitungan Produk Domestik Bruto (PDB) dirumuskan sebagai berikut:

$\mathrm{PDB}=\mathrm{C}+\mathrm{I}+\mathrm{G}(\mathrm{X}-\mathrm{M})$

Ket:

$\mathrm{C}=$ Konsumsi rumah tangga

$\mathrm{I}=$ Perusahaan, berupa investasi/pembentukan modal bruto $\mathrm{G}=$

Pengeluaran pemerintah (konsumsi/belanja pemerintah) (X-M)

$=$ Ekspor - Impor.

Suku Bunga Bank Indonesia (SBBI) adalah suku bunga kebijakan yang mencerminkan 
sikap atau stance kebijakan moneter yang ditetapkan oleh Bank Indonesia dan diumumkan kepada publik oleh Dewan Gubernur Bank Indoonesia setiap rapat dewan gubernur bulanan.

Inflasi adalah proses kenaikan harga-harga umum barang- barang secara terus menerus. Kenaikan harga ini diukur dengan menggunakan indeks harga berupa indeks harga konsumen (consumer price index), Indeks harga perdagangan besar (wholesale price index), dan GDP deflator. Perhitungan inflasi dirumuskan sebagai berikut:

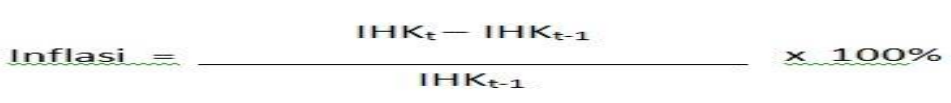

Ket:

$\mathrm{IHKt}=$ Indeks Harga tahunan tertentu (dihitung)

IHKt-1= Indeks Harga tahun sebelumnya

Kurs adalah harga satu unit mata uang asing dalam mata uang domestik atau dapat juga dikatakan harga mata uang domestik terhadap mata uang asing. Contoh nlai tukar rupiah dalam valuta asing;

NTIDR/USD = Rupiah yang diperlukan untuk membeli 1 dolar Amerika(USD) NTIDR/YEN = Rupiah yang diperlukan untuk membeli satu Yen Jepang

Hipotesis dan kerangka pemikiran menggunakan variabel dependen dan independen.

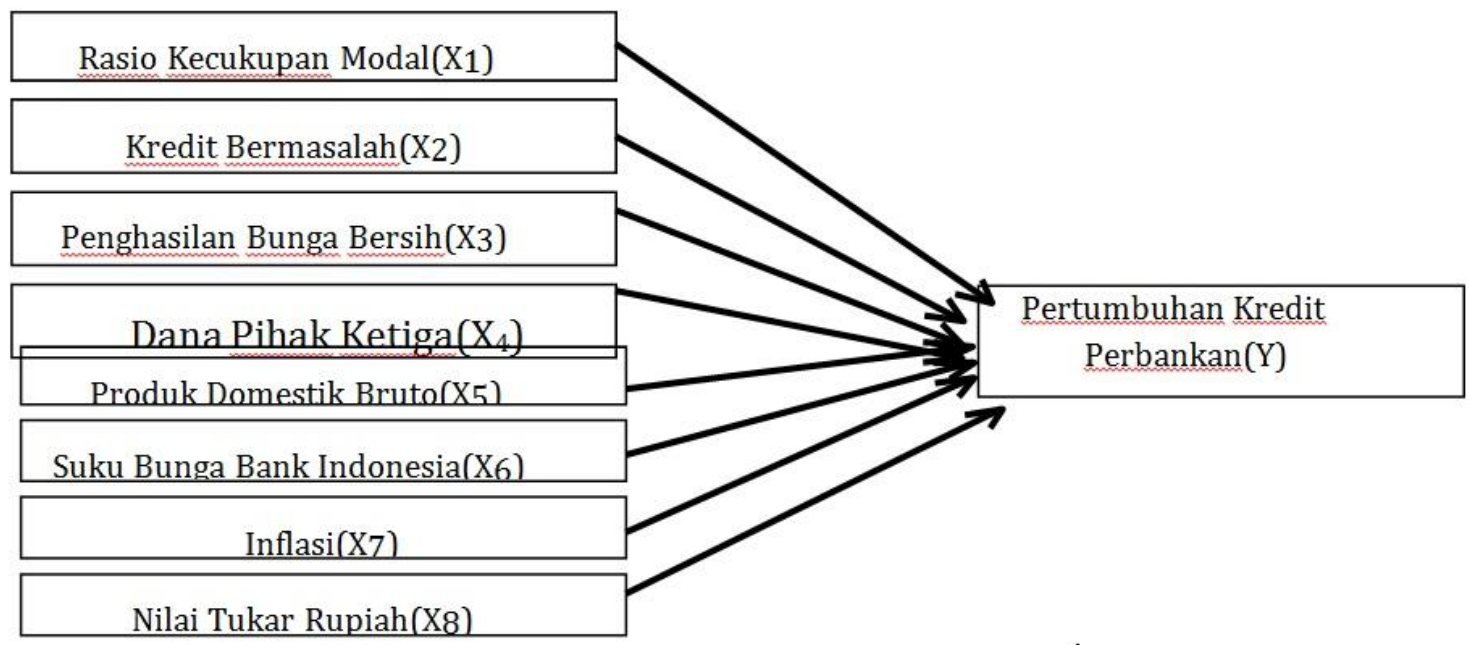

Variabel Independen

Sumber: DataPenulis

\section{Nariabel Dependen}

Dari kerangka pemikiran diatas maka terbentuklah persamaan yang akan penulis gunakan yakni sebagai berikut:

$Y_{t}=\beta_{0}+\beta_{1} \cdot X_{1}(t-1)+\beta 2 . X 2(t-1)+\beta 3 . X 3(t-1)+\beta 4 . X 4(t-1)+\beta 5 . X 5(t-1)+\beta 6 . X 6(t-1)+$ B7.X7(t-1) + 38.X8(t-1) +eí

Ket: 


\section{saki}

Studi Akuntansi \& Keuangan Indonesia

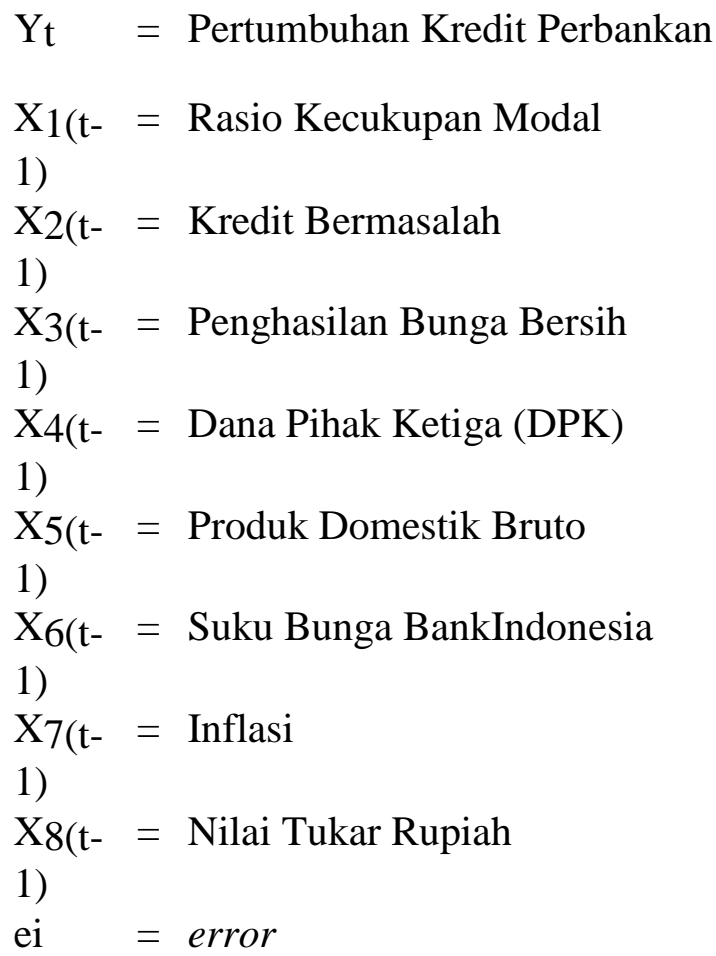

\section{METODE PENELITIAN}

Penelitian ini menggunakan metode kuantitatif berlandaskan filsafat positivisme karena memenuhi kaidah-kaidah ilmiah yaitu konkrit/empiris, obyektif, terukur, rasional, dan sistematis. Variabel penelitian yang digunakan adalah variabel dependen dan variabel independen. Variabel dependen yang digunakan penulis adalah pertumbuhan total kredit yang disalurkan oleh bank yang tergabung dalam Bank Umum Kelompok Usaha (BUKU) 4 yakni BCA, BNI, BRI dan Mandiri kepada nasabahnya yang disajikan dalam bentuk persentase. Variabel independen yang digunakan dalam penelitian ini dibedakan atas dua faktor yaitu internal dan eksternal. Faktor internal ialah rasio kecukupan modal (CAR), kredit bermasalah (NPL), penghasilan bunga bersih (NIM), dan Dana Pihak Ketiga (DPK), sementara faktor eksternal adalah Produk Domestik Bruto (PDB), Suku Bunga Bank Indonesia (SBBI), inflasi, dan nilai tukar Rupiah dari masing-masing bank yang tergabung dalam Bank Umum Kelompok Usaha (BUKU) 4 yakni BCA, BNI, BRI dan Mandiri. Adapun data rasio kecukupan modal (CAR), kredit bermasalah (NPL), penghasilan bunga bersih (NIM), dan Dana Pihak Ketiga (DPK), Suku Bunga Bank Indonesia (SBBI), inflasi disajikan dalam bentuk persentase. Sementara, Produk Domestik Bruto (PDB) dan nilai tukar Rupiah disajikan dalam bentuk nominal.

Sumber data berasal dari laporan keuangan tahunan bank umum pada kategori Bank Umum Kelompok Usaha (BUKU) 4 yakni BCA, BNI, BRI, dan Mandiri yang telah dipublikasikan pada laman resmi bank dan studi kepustakaan.

Metode yang digunakan dalam penelitian ini adalah regresi panel yang mencakup berbagai jenis data dengan jangkauan periode yang luas. Metode ini diuji dengan Uji Asumsi Klasik yang terdiri dari Uji Multikolinearitas dan Uji Autokorelasi

Untuk menguji keakuratan hasil penelitian ini penulis mengadakan pengujian hipotesis yang dilakukan dengan cara uji Statistik F, uji Statistik t, dan uji Fit R2. 


\section{HASIL PENELITIAN DAN PEMBAHASAN}

Dana Pihak Ketiga (DPK), rasio kecukupan modal, kredit bermasalah, Suku Bunga Bank Indonesia (SBBI), dan Produk Domestik Bruto (PDB) berpengaruh signifikan bagi pertumbuhan kredit perbankan di Indonesia, sementara inflasi, penghasilan bunga bersih, dan nilai tukar Rupiah tidak berpengaruh signifikan. Berikut ini adalah hasil penelitian yang mendukung pernyataan ini.

\section{Bank Mandiri}

Bank Mandiri mencatatkan pertumbuhan kredit sebesar 81\% dari kuartal 2 tahun 2005 sampai dengan kuartal 2 tahun 2015 sebagaimana yang dapat dilihat pada kedua grafik berkitu;
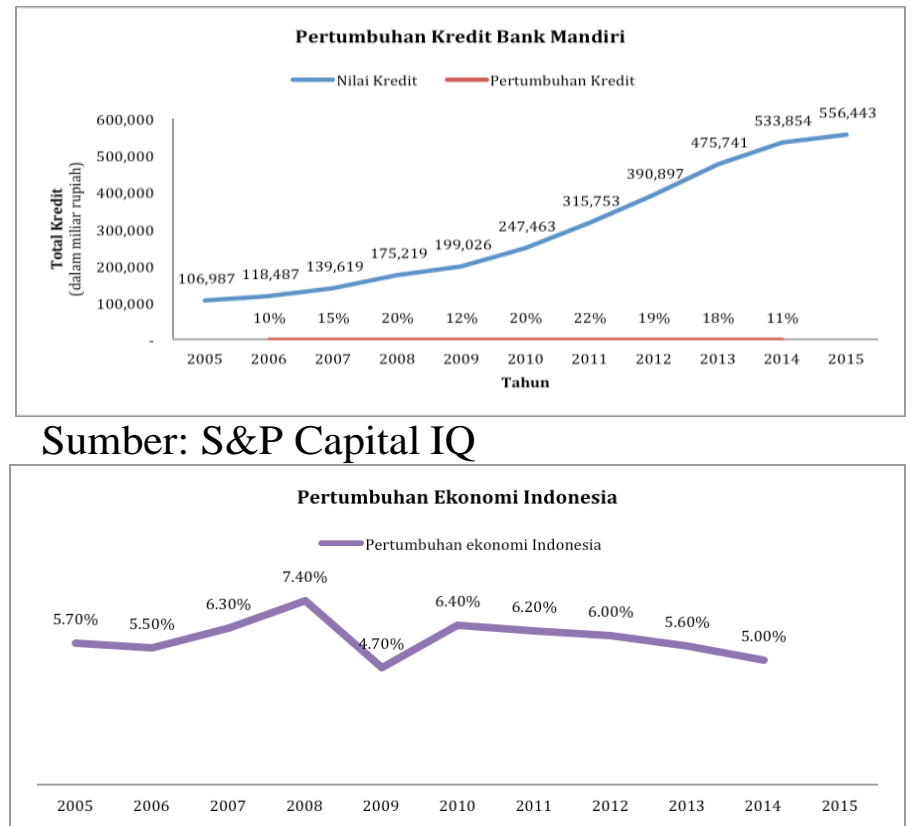

Sumber: Worldbank.org

Pertumbuhan kredit Bank Mandiri yang stabil dikontribusikan oleh rasio kecukupan modal yang relatif stabil diatas $8 \%$, rasio kredit bermasalah yang turun secara signifikan dan relatif stabil tetap terjaga dibawah 5\%, Dana Pihak Ketiga (DPK) yang tumbuh signifikan setiap tahun serta penghasilan bunga bersih yang relatif stabil.

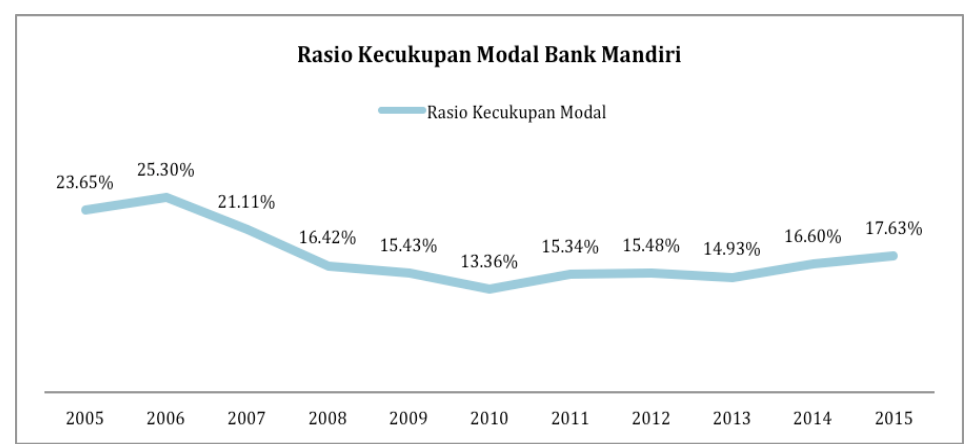

Sumber: Laporan Keuangan Bank Mandiri 
Rasio kecukupan modal Bank Mandiri pada tahun 2005 hingga tahun 2010 mengalami tren menurun akibat pertumbuhan Domestik Bruto (PDB) meningkat dan kebutuhan kredit meningkat. Sementara pada tahun 2010 hingga tahun 2015 tren rasio kecukupan modal Bank Mandiri mulai mengalami kenaikan dan cenderung stabil, hal tersebut karena rasio kredit bermasalah memperlihatkan tren menurun dari tahun 2005 hingga 2010, bahkan sepanjang tahun 2010 hingga tahun 2015 rasio kredit bermasalah relatif stabil terjaga dibawah $3 \%$.

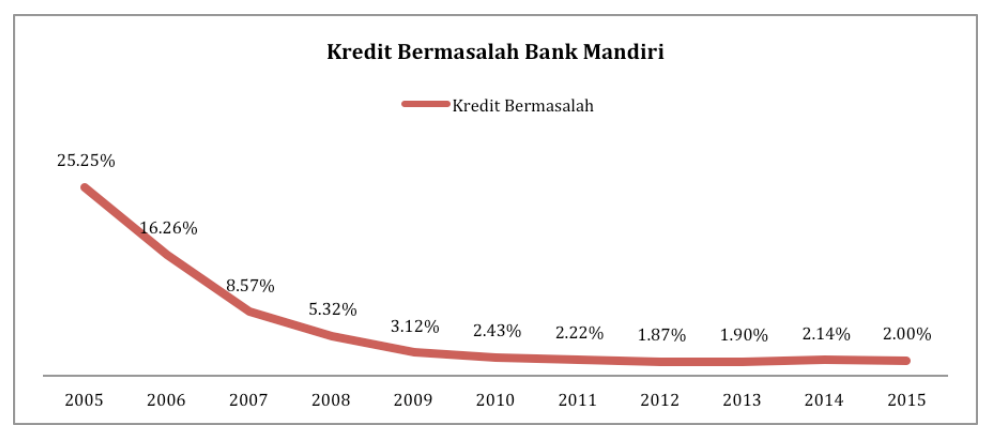

Sumber: Laporan Keuangan Bank Mandiri

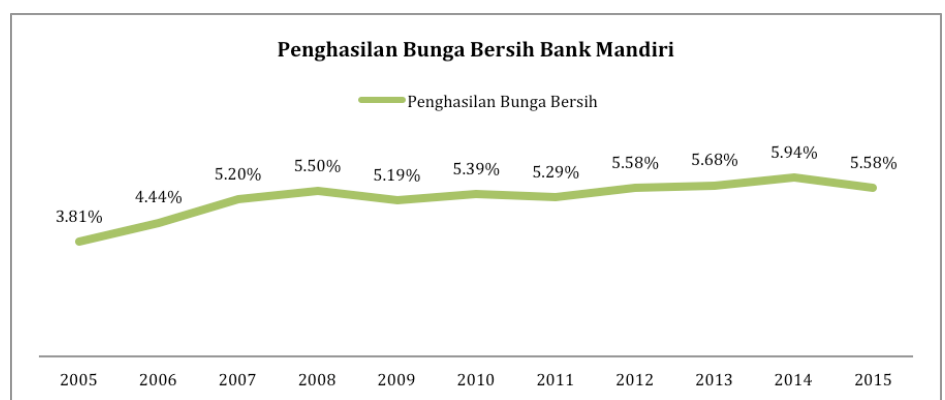

Sumber: Laporan Keuangan Bank Mandiri

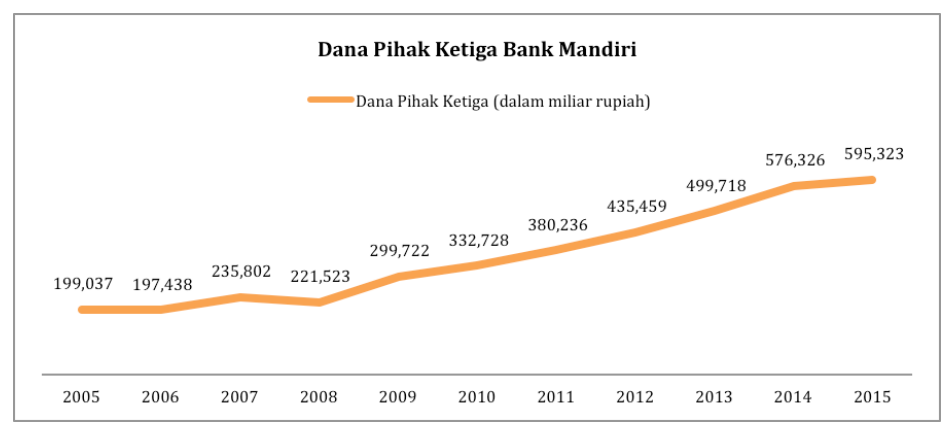

Sumber: Laporan Keuangan Bank Mandiri

\section{Bank BCA}

Bank BCA mencatatkan pertumbuhan kredit sebesar 88\% dari kuartal 2 tahun 2005 sampai dengan kuartal 2 tahun 2015. Pertumbuhan kredit Bank BCA relatif stabil sebagaimana tampak pada grafik berikut. 
saki

Studi Akuntansi \& Keuangan Indonesia

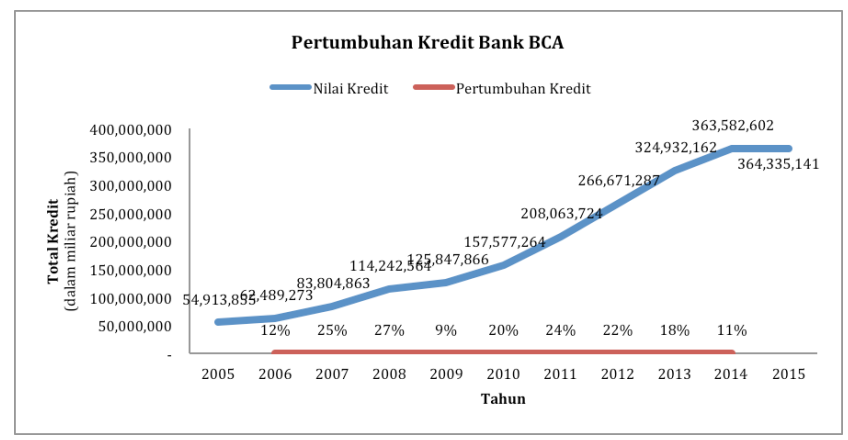

Sumber: S\&P Capital IQ

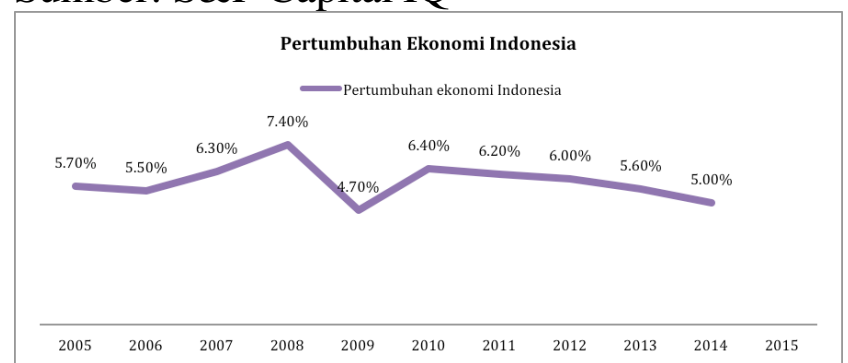

Sumber: Worldbank.org

Pertumbuhan kredit Bank BCA yang stabil dikontribusikan oleh rasio kecukupan modal yang relatif stabil diatas $8 \%$, rasio kredit bermasalah yang turun secara signifikan dan relatif stabil tetap terjaga dibawah 5\%, Dana Pihak Ketiga (DPK) yang tumbuh signifikan setiap tahun serta penghasilan bunga bersih yang relatif stabil.

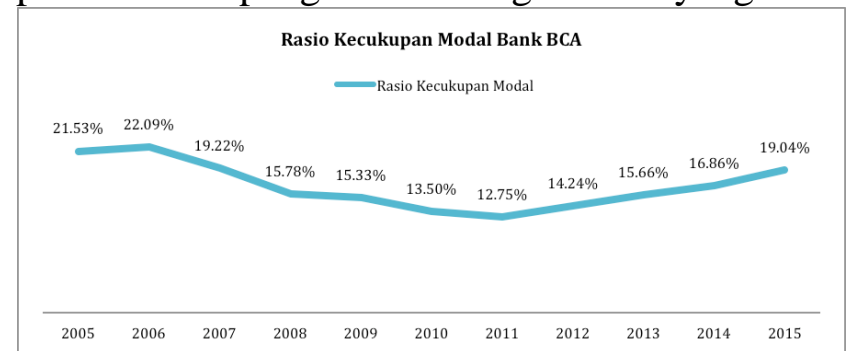

Sumber: Laporan Keuangan Bank BCA

Rasio kecukupan modal Bank BCA tahun 2005 hingga tahun 2011 mengalami tren menurun, hal ini dikarenakan Pertumbuhan Domestik Bruto (PDB) meningkat dan kebutuhan kredit meningkat.

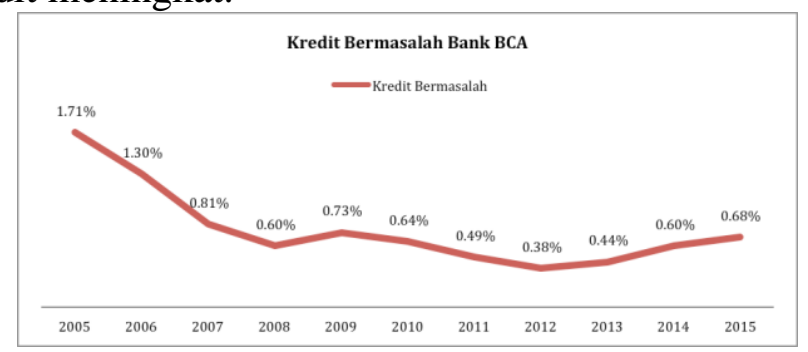

Sumber: Laporan Keuangan Bank BCA 
saki

Studi Akuntansi \& Keuangan Indonesia

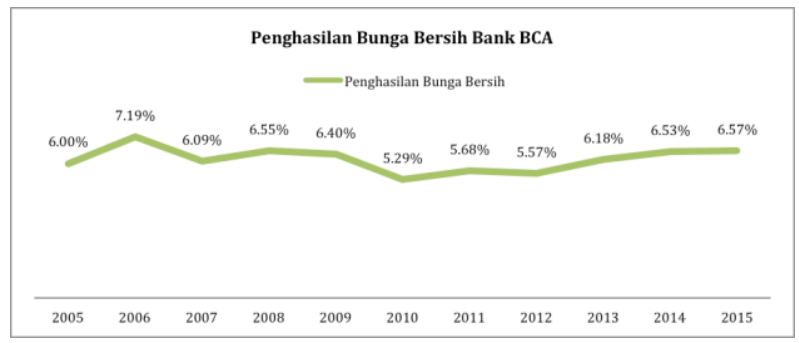

Sumber: Laporan Keuangan Bank BCA

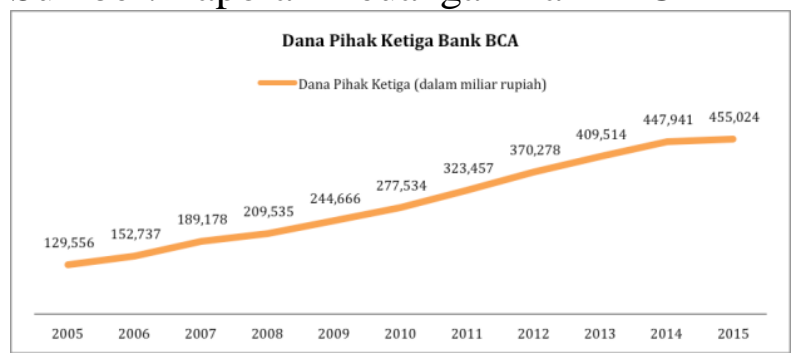

Sumber: Laporan Keuangan Bank BCA

\section{Bank BNI}

Bank BNI mencatatkan pertumbuhan kredit sebesar 79\% dari kuartal 2 tahun 2005 sampai dengan kuartal 2 tahun 2015 sebagaimana yang dapat dilihat pada grafik berikut

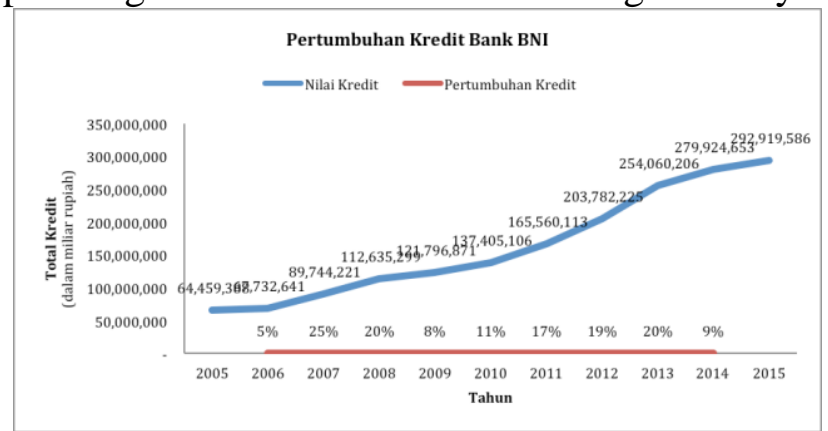

Sumber: S\&P Capital IQ

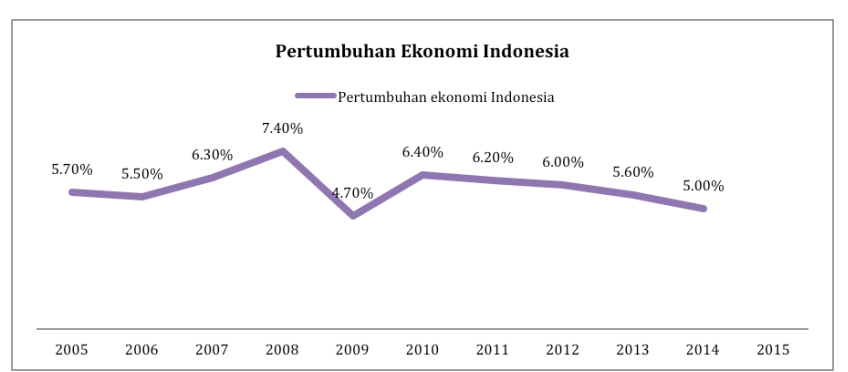

Sumber: Worldbank.org

Pertumbuhan kredit Bank BNI yang stabil dikontribusikan oleh rasio kecukupan modal yang relatif stabil di atas $8 \%$, rasio kredit bermasalah yang turun, bahkan pada tahun tahun 2011 hingga tahun 2015 dapat terjaga dibawah 5\%, Dana Pihak Ketiga (DPK) yang tumbuh signifikan dan penghasilan bunga bersih yang relatif stabil. 


\section{saki}

Studi Akuntansi \& Keuangan Indonesia

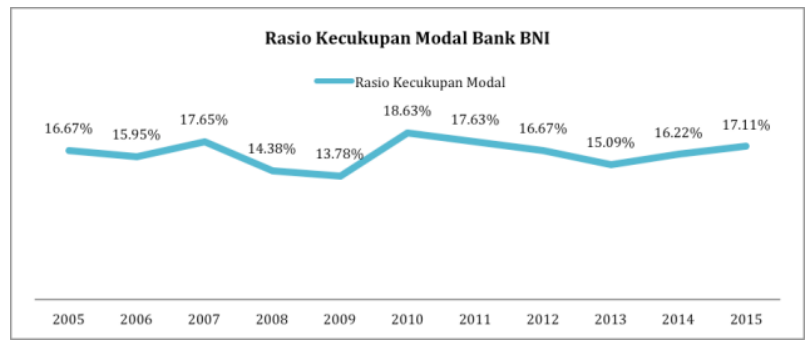

Sumber: Laporan Keuangan Bank BNI

Rasio kecukupan modal Bank BNI pada tahun 2005 hingga tahun 2009 mengalami tren menurun, hal ini dikarenakan Pertumbuhan Domestik Bruto (PDB) meningkat dan kebutuhan kredit meningkat. Sementara pada tahun 2010 hingga tahun 2015 tren rasio kecukupan modal Bank BNI mulai mengalami kenaikan dan cenderung stabil, hal tersebut karena rasio kredit bermasalah memperlihatkan tren menurun dari tahun 2005 hingga 2009, bahkan sepanjang tahun 2010 hingga tahun 2015 rasio kredit bermasalah relatif stabil terjaga dibawah 5\%. Begitupun dengan Dana Pihak Ketiga (DPK) yang tidak terpengaruh pertumbuhannya pada tahun 2008 hingga tahun 2009, bahkan mengalami tren naik. Serta penghasilan bunga bersih yang relatif stabil dari tahun 2008 hingga tahun 2015 .

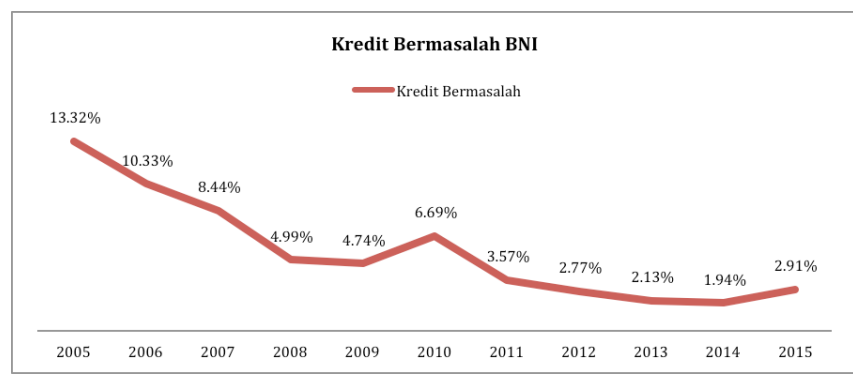

Sumber: Laporan Keuangan Bank BNI

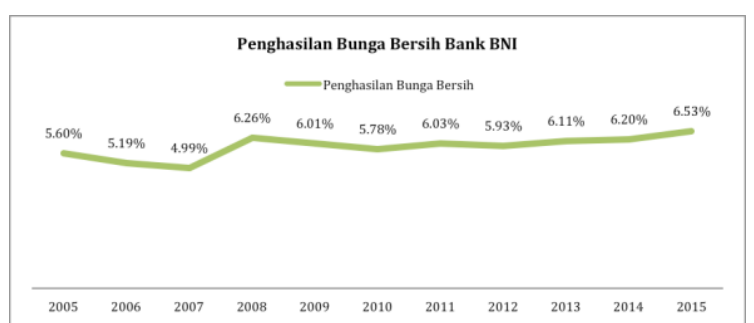

Sumber: Laporan Keuangan Bank BNI

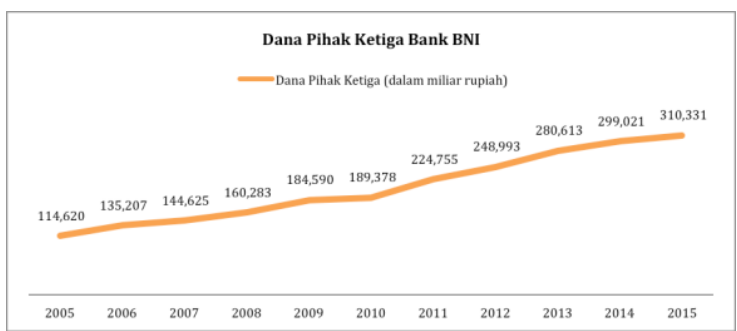

Sumber: Laporan Keuangan Bank BNI

\section{Bank BRI}

Bank BRI mencatatkan pertumbuhan kredit sebesar 87\% dari kuartal 2 tahun 2005 
sampai dengan kuartal 2 tahun 2015. Pertumbuhan kredit Bank BRI relatif stabil, dapat dilihat pada grafik berikut;

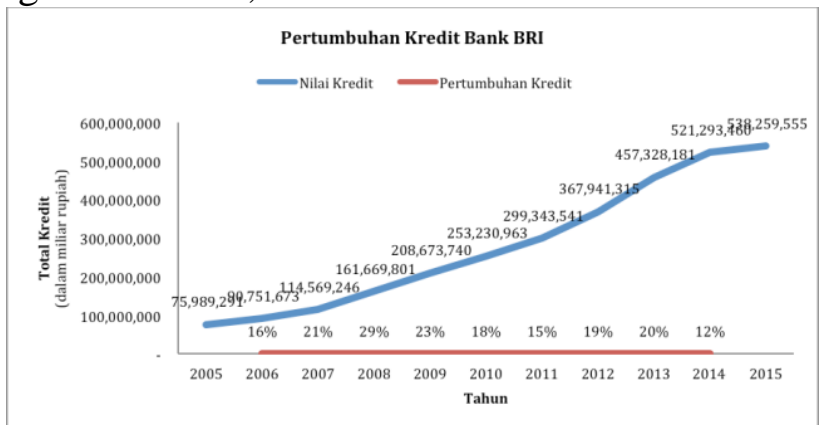

Sumber: S\&P Capital IQ

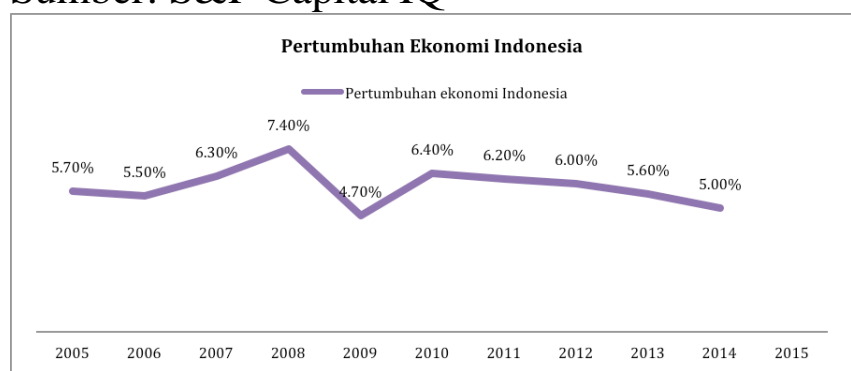

Sumber: Worldbank.org

Pertumbuhan kredit Bank BRI yang stabil dikontribusikan oleh rasio kecukupan modal yang relatif stabil di atas $8 \%$, rasio kredit bermasalah yang turun, bahkan pada tahun tahun 2011 hingga tahun 2015 dapat terjaga dibawah 5\%, Dana Pihak Ketiga (DPK) yang tumbuh signifikan dan penghasilan bunga bersih yang relatif stabil.

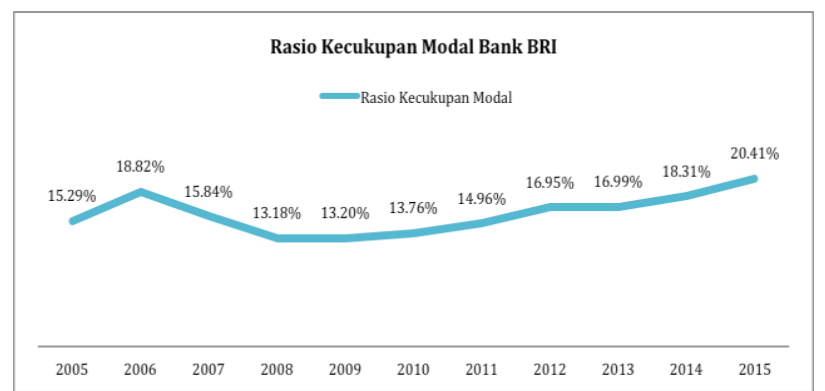

Sumber: Laporan Keuangan Bank BRI

Rasio kecukupan modal Bank BRI tahun 2005 hingga tahun 2010 mengalami tren menurun, karena Pertumbuhan Domestik Bruto (PDB) meningkat dan kebutuhan kredit meningkat. Sementara pada tahun 2010 hingga tahun 2015 tren rasio kecukupan modal Bank BRI cenderung stabil, karena rasio kredit bermasalah memperlihatkan tren menurun dari tahun 2005 hingga 2015, bahkan relatif stabil terjaga dibawah 5\%. Begitupun dengan Dana Pihak Ketiga (DPK) yang tidak terpengaruh pertumbuhannya pada tahun 2008 hingga tahun 2009, bahkan mengalami tren naik. Serta penghasilan bunga bersih yang relatif stabil dari tahun 2008 hingga tahun 2015. 
saki

Studi Akuntansi \& Keuangan Indonesia

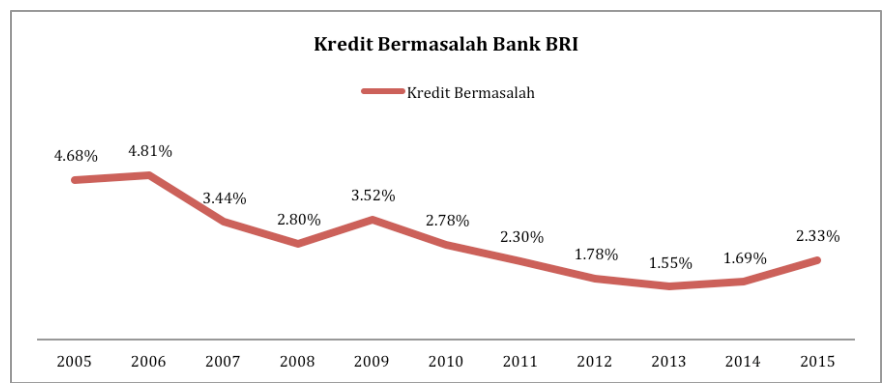

Sumber: Laporan Keuangan Bank BRI

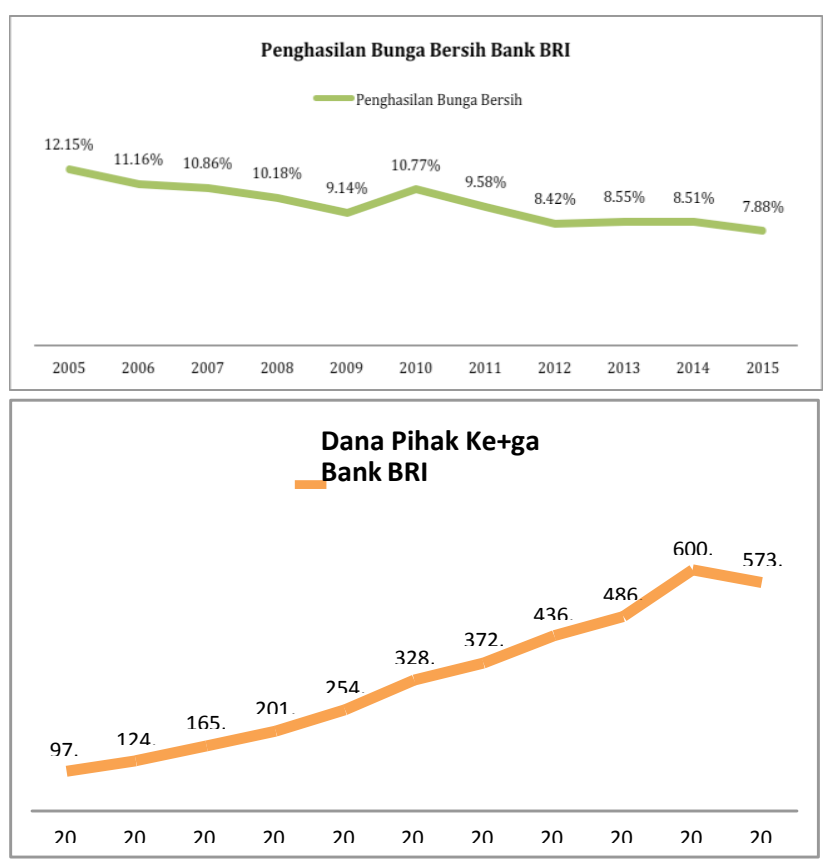

Sumber: Laporan Keuangan Bank BRI

Untuk menjawab tujuan penelitian seperti yang telah disampaikan pada bab 1, maka penulis akan menguji faktor internal terhadap pertumbuhan kredit perbankan, faktor eksternal terhadap pertumbuhan kredit perbankan, dan kombinasi kedua faktor terhadap pertumbuhan kredit perbankan.

\section{Hasil Regresi Kombinasi Faktor Internal dan Eksternal}

\begin{tabular}{lc}
\hline VARIARLES & (Model 3) \\
\hline rasiokecukupan & 0.343 \\
modal & $* *$ \\
kreditbermasalah & $(0.160$ \\
Penghasilanbungabersih & 0.054
\end{tabular}




\section{saki}

\begin{tabular}{ll} 
produkdomestikbru & $8)$ \\
to & 0.083 \\
sukubungabankind & $*$ \\
onesia & $(0.04$ \\
Inflasi & $6)$ \\
& 0.160 \\
Nilaitukarrupiah & $(0.207)$ \\
& 0.003 \\
Constant & $(0.089)$ \\
& -0.023 \\
Observations & $(0.072)$ \\
R-squared & 156 \\
Adj R-squared & 0.1197 \\
\hline Standard errors in parentheses & 0.0718 \\
$* * * p<0.01, * * \mathrm{p}<0.05, * \mathrm{p}<0.1$ & \\
& PDB dinyatakan dalam ribuan triliun \\
& Rupiah Variabel lainnya \\
& dinyatakan dalam \%
\end{tabular}

Sumber: Perhitungan Penulis

Hasil Regresi Pengaruh Faktor Internal Terhadap Pertumbuhan Kredit Perbankan, faktor internal memiliki nilai Prob>F sebesar 0.1046 dimana lebih besar dari Alpha 0.05. Model ini tidak signifikan dan tidak layak untuk dibahas lebih lanjut. Begitupun dengan Hasil Regresi Pengaruh Faktor Eksternal Terhadap Pertumbuhan Kredit Perbankan yang memiliki nilai Prob>F sebesar 0.0905 dimana lebih besar dari Alpha 0.05. Sementara itu, berdasarkan Hasil Regresi Pengaruh Kombinasi Faktor Internal dan Faktor Eksternal diketahui bahwa kombinasi dari faktor internal dan eksternal memiliki nilai Prob>F sebesar 0.0142. Selain itu data penulis juga memiliki Adjusted $\mathrm{R}^{2}$ sebesar 0.0718 yang berarti variabel dependen dapat dijelaskan $7.18 \%$ dengan 8 variabel independen yang diuji. Sedangkan sisanya yaitu sebesar $92.82 \%$ dijelaskan oleh variabel yang tidak diuji.

Pada model kombinasi antara faktor internal dan faktor eksternal terdapat beberapa variasi tingkat signifikansi pada variabel independen. Variabel independen yang mempengaruhi pertumbuhan kredit dengan tingkat signifikansi dibawah $10 \%$ adalah Dana Pihak Ketiga (DPK). Adapun variabel independen yang mempengaruhi pertumbuhan kredit yang disalurkan dengan tingkat signifikansi dibawah 5\% antara lain rasio kecukupan modal, kredit bermasalah, dan Suku Bunga Bank Indonesia (SBBI). Sementara variabel independen yang mempengaruhi pertumbuhan kredit yang disalurkan dengan tingkat signifikansi dibawah $1 \%$ adalah Produk Domestik Bruto (PDB).

Dapat dilihat berdasarkan masing-masing koefisien, Dana Pihak Ketiga (DPK) memiliki koefisien sebesar 0.083 yang berarti setiap kenaikan DPK sebesar $1 \%$, maka pertumbuhan kredit akan naik sebesar $0.083 \%$. Selanjutnya adalah rasio kecukupan modal dengan koefisien sebesar 0.3428 yang berarti pada setiap kenaikan rasio kecukupan modal sebesar $1 \%$, maka pertumbuhan kredit akan naik sebesar $0.3428 \%$. Kredit bermasalah yang memiliki koefisien sebesar -0.2085 berarti setiap kenaikan sebesar $1 \%$, pertumbuhan kredit 
akan turun sebesar $0.2085 \%$. Suku Bunga Bank Indonesia (SBBI) yang memiliki koefisien sebesar 0.0082 berarti setiap kenaikan SBBI sebesar 1\%, pertumbuhan kredit akan naik sebesar $0.0082 \%$. Begitu pula dengan Produk Domestik Bruto (PDB) yang memiliki koefisien sebesar -0.184 . Setiap kenaikan PDB sebesar 1\%, pertumbuhan kredit akan turun sebesar $0.184 \%$. Dari hasil regresi didapatkan persamaan berikut:

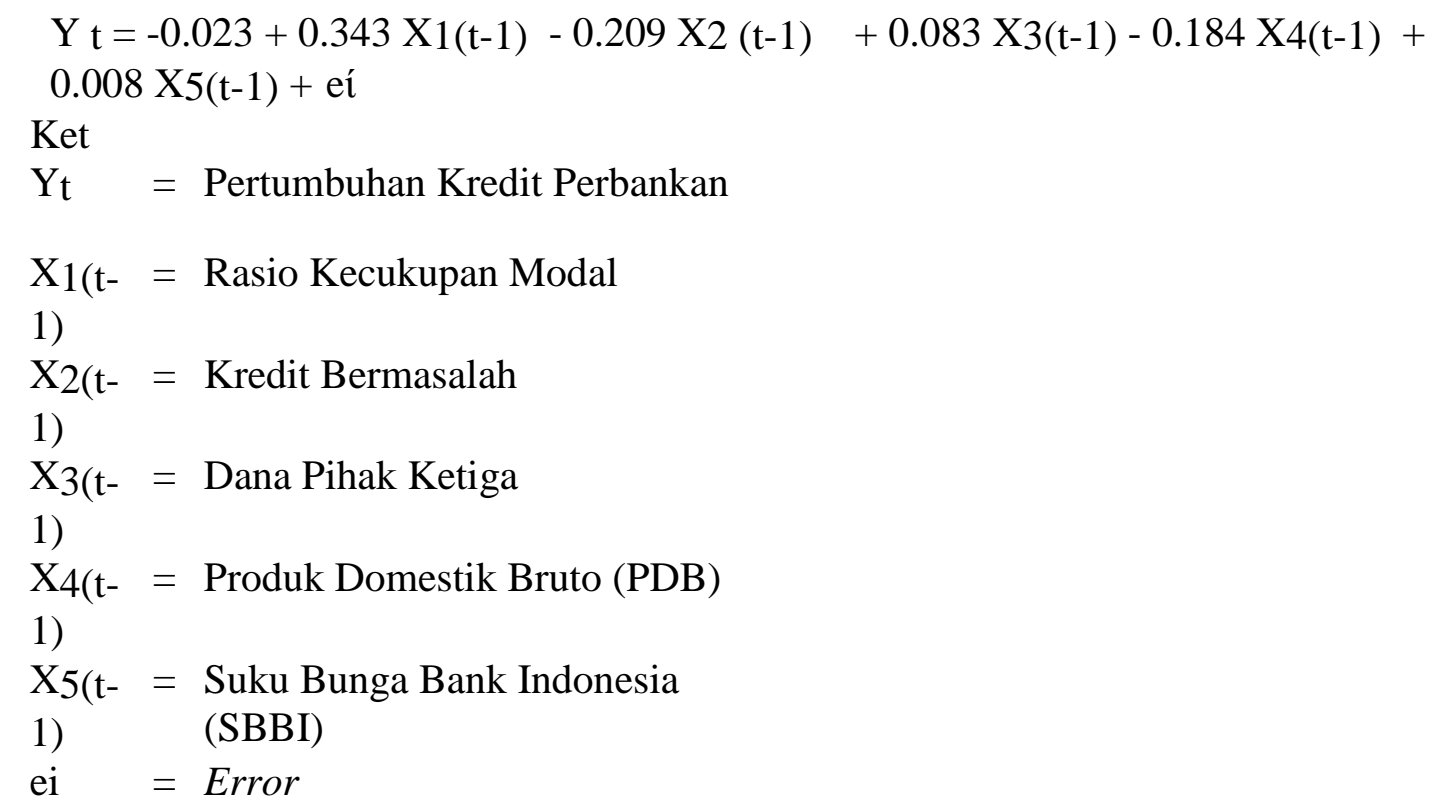

Dari persamaan tersebut, terdapat lima variabel signifikan yakni rasio kecukupan modal, kredit bermasalah, Dana Pihak Ketiga (DPK), Produk Domestik Bruto (PDB), dan Suku Bunga Bank Indonesia (SBBI) yang mempengaruhi pertumbuhan kredit perbankan. Berdasarkan hasil tersebut bank lebih fokus pada kelima variabel signifikan demi meningkatkan dan meramalkan pertumbuhan kredit kedepan. Selain itu, bank dapat mengetahui lebih dalam mengenai kinerja internal bank dan juga meramalkan kinerja bank lain yang merupakan pesaingnya.

\section{KESIMPULAN}

Berdasarkan hasil penelitian disimpulkan bahwa melalui uji-F atau global test, secara bersama-sama seluruh variabel bebas yang diteliti memiliki pengaruh yang signifikan terhadap variabel terikat dengan nilai signifikansi sebesar 0.0142 pada model 3 (gabungan). pada model 1 (internal) dan model 2 (eksternal), setiap variabel dari kedua model tidak memiliki pengaruh yang signifikan terhadap variabel dependen. Melalui uji-t atau uji parsial, didapatkan hasil secara parsial, terdapat 5 variabel yang signifikan pada model 3 (gabungan) yaitu, Dana Pihak Ketiga (DPK) dengan tingkat signifikansi dibawah 10\%, rasio kecukupan modal, kredit bermasalah dan Suku Bunga Bank Indonesia (SBBI) yang memiliki tingkat signifikansi dibawah 5\% dan Produk Domestik Bruto (PDB) dengan tingkat signifikansi dibawah 1\%. Sedangkan variabel penghasilan bunga bersih, inflasi dan nilai tukar Rupiah terbukti tidak memiliki pengaruh signifikan terhadap pertumbuhan kredit perbankan pada bank BUKU 4 berdasarkan model 3 (gabungan). Analisis uji fit $\mathrm{R}^{2}$ menghasilkan nilai Adjusted $\mathrm{R}^{2}$ sebesar 0.0718. Hal ini menunjukkan bahwa nilai pertumbuhan penyaluran kredit perbankan pada bank BUKU 4 dapat dijelaskan menggunakan variabel Dana Pihak Ketiga (DPK), rasio kecukupan modal, kredit bermasalah, Suku Bunga Bank Indonesia (SBBI), 


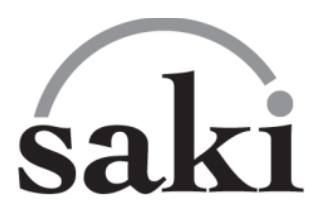

Studi Akuntansi \& Keuangan Indonesia

Produk Domestik Bruto (PDB), pengahasilan bunga bersih, inflasi, dan nilai tukar Rupiah sebesar $7.18 \%$. Sedangkan sisanya dipengaruhi oleh faktor lain yang tidak diteliti oleh peneliti.

Berdasarkan hasil uji regresi terhadap pertumbuhan penyaluran kredit perbankan pada model 3 (gabungan), didapatkan hasil bahwa variabel rasio kecukupan modal, Dana Pihak Ketiga (DPK) dan Suku Bunga Bank Indonesia (SBBI) memiliki pengaruh positif terhadap pertumbuhan penyaluran kredit perbankan, variabel kredit bermasalah dan Produk Domestik Bruto (PDB) memiliki pengaruh negatif terhadap pertumbuhan penyaluran kredit perbankan. Sedangkan variabel penghasilan bunga bersih, inflasi dan nilai tukar Rupiah tidak memiliki pengaruh terhadap pertumbuhan penyaluran kredit perbankan. Adapun pengaruh dari sebagian variabel yang mendukung hasil penelitian sebelumnya seperti penelitian yang telah dilakukan sebelumnya oleh (Satria dan Subegti, 2010), (Oktaviani dan Pangestuti, 2012), (Suarni, Kirya dan Yudiaatmaja, 2013), (Sulistya dan Wirakusuma, 2013), (Nugraheni dan Meiranto, 2013), dan (Suryawati, Cipta dan Susila, 2014) bahwa rasio kecukupan modal berpengaruh signifikan positif terhadap penyaluran kredit perbankan.

Penelitian yang dilakukan oleh (Oktaviani dan Pangestuti, 2012), (Yuda dan Meiranto, 2013), (Fitria, Saryadi, dan Wijayanto, 2013), (Sulistya dan Wirakusuma, 2013), (Jelantik dan Setiawina, 2013), (Saryadi, 2013), (Sari, 2013), (Suryawati, Cipta dan Susila, 2014), (Sariasih dan Dewi, 2014), dan (Siswati, 2015) yang menyatakan bahwa Dana Pihak Ketiga (DPK) berpengaruh signifikan positif terhadap penyaluran kredit perbankan. Penelitian yang dilakukan oleh (Rahayu, 2013), (Astuti, Hermani dan Saryadi, 2013), (Sari, 2013), (Nugraheni dan Meiranto, 2013), dan (Septiarini dan Ramantha, 2014) menyatakan bahwa kredit bermasalah berpengaruh signifikan negatif terhadap penyaluran kredit perbankan. Sedangkan untuk variabel Produk Domestik Bruto (PDB) dan Suku Bunga Bank Indonesia (SBBI) memiliki pengaruh yang berlawanan dari penelitian yang telah dilakukan sebelumnya.

\section{DAFTAR PUSTAKA}

Astuti, Yuanita Resti, Agus Hermani, dan Saryadi. (2013). Pengaruh Tingkat Kesehatan Keuangan Terhadap Jumlah Kredit Yang Disalurkan Pada PD. BPR Bank Pasar Temanggung. Semarang: Universitas Diponegoro.

Ayu, Fitria, Saryadi, dan Andi Wijayanto. (2013). Pengaruh Dana Pihak Ketiga (DPK), Capital Adequacy Ratio (CAR), Non Performing Loan (NPL), Return On Assets (ROA) Dan Loan To Deposit Ratio (LDR) Terhadap Volume Kredit Yang Disalurkan Bank Persero. Semarang: Program Studi Administrasi Bisnis Universitas Diponegoro.

Bank Indonesia. (2016, Mei 15). Penjelasan BI Rate Sebagai Suku Bunga Acuan: http://www.bi.go.id/id/moneter/bi- rate/penjelasan/Contents/Default.aspx.

Bank Indonesia.(2016, Mei 15). Produk Domestik Bruto:

http://www.bi.go.id/id/statistik/metadata/sekda/Documents/8PDRBSEK DA1.pdf

Budisantoso, Totok dan Nuritomo. (2014). Bank dan Lembaga Keuangan Lain Edisi 3. Jakarta: Salemba Empat.

Departemen Penelitian dan Pengaturan PerbankanBank Indonesia. (2016, April 14).

Consultative Paper Basel III: Global Regulatory Framework For More Resilient Banks and

Banking systems:http://www.bi.go.id/id/perbankan/implementasi-basel/consultativeapers/Documents/9bf8e496156149f1a9bfdcc31e9758bepublishedCPB3. pdf

Dornbusch, R., S. Fischer, \& R. Starts. (2011). Macroeconomics (11th ed.). New York: Mc Graw Hill. 


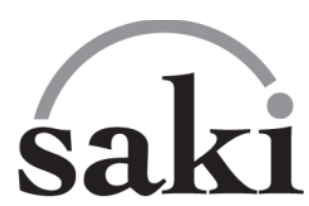

Studi Akuntansi \& Keuangan Indonesia

Gujarati, Damodar N. (2004). Basic Econometrics Fourth Edition. New York: Tata McGrawHill.

Halim, Levina. (2013). Pengaruh Makroekonomi dan Ekspor Terhadap Kredit Modal Kerja dan Kredit Investasi Perbankan. Finesta Vol. 1, No. 2, hal. 1-6.

Ivanovic, Maja. (2016). Determinants of Credit Growth: The Case of Montenegro. Journal of Central Banking Theory and Practice, 2016, 2, hal. 101-118.

Jelantik, I G A Utama Dewi dan Nyoman Djinar Setiawina. (2013). Beberapa Faktor Yang Mempengaruhi Jumlah Kredit Konsumtif Pada Bank Umum Di Bali Tahun 2004-2012.

Denpasar: Fakultas Ekonomi Universitas Udayana.

Nopirin, Ph.D. 2011. Pengantar Ilmu Ekonomi Makro \& Mikro Edisi Pertama. Yogyakarta: BPFE-Yogyakarta (anggota IKAPI).

Nugraheni, Putri Pratista dan Wahyu Meiranto. (2013). Pengaruh Faktor Internal Bank Dan Sertifikat Bank Indonesia Terhadap Penyaluran Kredit Perbankan Di Indonesia. Diponegoro Journal of Accounting, Volume 2, Nomor 4, Tahun 2013, Hal. 1-11.

Oktaviani, Irene Rini Demi Pangestuti. (2012). Pengaruh DPK, ROA, CAR, NPL, Dan Jumlah SBI Terhadap Penyaluran Kredit Perbankan (Studi Pada Bank Umum Go Public di Indonesia Periode 2008-2011). Semarang: Diponegoro Journal of Management. Volume 1, Nomor 2, Tahun 2012, hal 430-438.

Peraturan Bank Indonesia No. 7/3/PBI/2005. Tentang Batas Maksimum Pemberian Kredit Bank Umum.

Peraturan Bank Indonesia No. 8/13/PBI/2006. Tentang Perubahan Atas Peraturan Bank Indonesia Nomor 7/3/PBI/2005 Tentang Batas Maksimum Pemberian Kredit Bank Umum.

Peraturan Bank Indonesia No. 14/18/PBI/2012. Tentang Kewajiban Penyediaan Modal Bank Umum.

Pernyataan Standar Akuntansi Keuangan (PSAK) No. 31. 1994. Tentang Akuntansi Perbankan.

Rahayu, Yoseva Maria Puji. (2013). Analisis Pengaruh Capital Adequacy Ratio, Return On Asset, Non Performing Loan Dan Suku Bunga SBI Terhadap Jumlah Kredit Yang Disalurkan Bank. Malang: Fakultas Ekonomi dan Bisnis Universitas Diponegoro.

Rivai, Veithzal, Andria Permata Veithzal, dan Ferry N. Idroes. (2007). Bank and Financial Institution Management, Conventional \& Sharia System. Jakarta: PT RajaGrafindo Persada.

Rokhim, Rofikoh dan Yinylia Rusli. 2012. Macro Economics Factors And Bank Lending Behaviour In Indonesia. Economic Journal of Emerging Markets, 4(2), hal. 153- 162.

Rose, Peter S. dan Sylvia C. Hudgins. (2010). Bank Management \& Financial Services Eight Edition. New York: McGraw-Hill.

Sari, Greydi Normala. (2013). Faktor-Faktor Yang Mempengaruhi Penyaluran Kredit Bank Umum Di Indonesia (Periode 2008.1-2012.2). Jurnal EMBA Vol. 1 No. 3 September 2013, hal. 931-941.

Sariasih, Ni Wayan dan Made Rusmala Dewi. (2013). Pengaruh Dana Pihak Ketiga, Non Performing Loan Dan Inflasi Terhadap Kredit Yang Disalurkan Oleh PD Kabupaten Badung Periode Tahun 2008-2012. Denpasar: Fakultas Ekonomi Dan Bisnis Universitas Udayana.

Saryadi. (2013). Faktor-Faktor Yang Berpengaruh Terhadap Penyaluran Kredit Perbankan (Studi Pada Bank Umum Swasta Nasional Devisa). Semarang: Jurnal Administasi Bisnis, Jurusan Administrasi Bisnis FISIP Universitas Diponegoro, Volume 2, Nomor 1, Maret 2013. 
Satria, Dias dan Rangga Bagus Subegti. (2010). Determinasi Penyaluran Kredit Bank Umum Di Indonesia Periode 2006-2009. Malang: Jurnal Keuangan dan Perbankan. Vol. 14, No. 3 September 2010, hal. 415-424.

Septriani, Ni Luh Sri dan I Wayan Ramantha. (2014). Pengaruh Rasio KecukupanModal Dan Rasio Penyaluran Kredit Terhadap Profitabilitas Dengan Moderasi Rasio Kredit Bermasalah. E-Jurnal Akuntansi Universitas Udayana 7.1 (2014), hal. 192-206.

Simorangkir, Iskandar dan Suseno. (2004). Seri Kebanksentralan No. 12 "Sistem dan Kebijakan Nilai Tukar”. Jakarta: Pusat Pendidikan Dan Studi Kebanksentralan (PPSK) Bank Indonesia.

Siswati. (2015). Analisis Pengaruh Dana Pihak Ketiga, Tingkat Suku Bunga Kredit, Dan Tiingkat Inflasi Terhadap Penyaluran Kredit. Jurnal Akuntansi dan Sistem Teknologi Informasi Vol. 11 Edisi Khusus Desember 2015, hal. 353-359.

Suarni, Kadek Sri, I Ketut Kirya, dan Fridayana Yudiaatmaja. (2013). Pengaruh Tingkat Suku Bunga Kredit, Tingkat Efisiensi Bank Dan Tingkat Kecukupan Modal Terhadap Jumlah Kredit Yang Disalurkan Pada PT Bank Perkreditan Rakyat Nur Abadi Tahun 2011-2013. EJournal Universitas Pendidikan Ganesha, Volume 2 Tahun 2014.

Sugiyono. (2009). Metode Penelitian Bisnis. Bandung: Alfabeta.

Sugiyono. (2010). Metode Penelitian Kuantitatif dan Kualitatif dan R\&D. Bandung: Alfabeta. Sulistya, Kadek Ari dan Made Gede Wirakusuma. (2013). Pengaruh Dana Pihak Ketiga, Capital Adequacy Ratio, Dan Suku Bunga Sertifikat Bank Indonesia Terhadap Penyaluran Kredit Bank BUMN Di Indonesia Periode 2006-2010. Denpasar: Fakultas Ekonomi Universitas Udayana.

Supriyatno. (2009). Metodologi Riset Bisnis. Jakarta: Jakarta Indeks.

Suryawati, Ni Made Anik Nasa, Wayan Cipta, dan Gede Putu Agus Jana Susila. (2014). Analisis Pengaruh Dana Pihak Ketiga (DPK), Capital Adequacy Ratio (CAR), Non Performing Loan (NPL), dan Loan to Deposit Ratio (LDR), Terhadap Jumlah Penyaluran Kredit (Studi Kasus Pada LDP Desa Pakraman Pemaron Periode 2010-2013). E-Journal Bima Universitas Pendidikan Ganesha Volume 2 Tahun 2014.

Susanty, Wahyu Devi. (2014). Pengaruh Faktor Internal Dan Eksternal Sebagai Penentu Fungsi Intermediasi Perbankan (Studi Pada Bank Syariah Dan Bank Umum Konvensional). Malang: Jurusan Ilmu Ekonomi Fakultas Ekonomi Dan Bisnis Universitas Brawijaya.

Tan, Tatum Blaise Pua. (2012). Determinants of Credit Growth and Interest Margins in the Philippines and Asia. International Monetary Fund Working Paper.

Tandris, Raimond, Parengkuan Tommy, dan Sri Murni. (2014). Suku Bunga, Inflasi, Dan Nilai Tukar Pengaruhnya Terhadap Permintaan Kredit Perbankan Di Kota Manado. Jurnal EMBA Vol. 2 No.1 Maret 2014, hal 243-253.

Undang-Undang Republik Indonesia Nomor 10 Tahun 1998. Tentang Perubahan atas Undang-Undang Nomor 7 Tahun 1992 tentang Perbankan.

Yuda, I Made Pratista dan Wahyu Meiranto. (2013). Pengaruh Faktor Internal Bank Terhadap Jumlah Kredit Yang Disalurkan (Studi Empiris Pada Bank Yang Terdaftar Di Bursa Efek Indonesia). Jurnal Akuntansi \& Auditing Volume 7/No. 1/ November 2010, hal. 94-110. 